\title{
Establishment of Reading Like Behavior of Elementary Students by Using Sustained Silent Reading Approach
}

\author{
Titik Purwati \\ Institute of Teacher Training and Education Budi Utomo \\ E-mail: titikpurwati62@gmail.com \\ Harun Ahmad \\ Institute of Teacher Training and Education Budi Utomo \\ E-mail: harun.a.sangaji@gmail.com \\ Dino Sudana \\ Institute of Teacher Training and Education Budi Utomo \\ E-mail: sukaurip@gmailcom
}

Received: May 20, 2017 Accepted: August 18, 2017 Published: August 18, 2017

doi:10.5296/jse.v7i3.11253 URL: https://doi.org/10.5296/jse.v7i3.11253

\begin{abstract}
The purpose of this research was to analyze the establishment of reading like behavior of Elementary School student in Malang City by using SSR approach. The research used survey and experimental methods which were applied to the third grade students in 5 Pubic Elementary Schools in Malang City. The samples were taken randomly. The data resources are from students, teachers, principals, and library staffs. The data were collected through observation, interviews, questionnaires, pre-and post-tests, and book read record. The data analyses used were descriptive analysis and $\mathrm{T}$ test. The research result was the application of the SSR approach has improved significantly to the reading like behavior of the students of Public Elementary Schools in Malang City. This result showed the SSR approach is suitable to be applied for the establishment of reading like behavior of Elementary School students.
\end{abstract}

Keywords: reading, like behavior, SSR approach 


\section{Introduction}

One of the markers that a nation has developed is reading activity. Indonesia has not made reading as a necessity. The reading interest is still low. According to the Law no. 43 in 2007 about libraries emphasize the need to establish reading culture. School is one of the important target of reading like culture. In harmony with the Law and the guidance of the character education implementation, reading is one of the 18 characters that must be developed in the process of education in schools (Ministry of National Education, 2011). The research report of Organization for Economic Cooperation and Development (OECD) published in 2010 for Programmers for International Student Assessment (PISA), Indonesia was rated in the $56^{\text {th }}$ rank from 65 countries for literacy test comparing the ability to read. Thailand was in the $49^{\text {th }}$ rank, Singapore in the $5^{\text {th }}$ rank (Jessica, 2010).

The learning essence in elementary school is a set of efforts to form a number of habits or behaviors having positive values, also emphasis on optimizing the ability to read, write, and count. The abilities that have been achieved need to be continued. The current condition of students is generally less interest in book, less interest in reading, and they prefer to watch television (Kartika, 2004). BPS revealed in 2006, that community has not made reading as the main source of information. People are more interested and choose to watch TV $(85.9 \%)$ and listen to radio (40.3\%) than reading newspapers (23\%) (www.bps.go.id, 2006).

Along with the development of technology and information, there are many products created by technology and information in the form of various products of children's toys that result in time for reading activities are ignored. As a result children's reading like behavior does not grow and decline from the previous years (Guthrie, JT, Bennet, L., \& McGough, Karen; 2009). On the other hand, the time used by students to read independently correlates significantly to the achievement of reading ability. Therefore reading is a tool that can give a guarantee for the lifelong learning inexpensively, independently, and flexibly.

Character means behavior, mental traits, morals or manners that distinguish one person from another, and nature (Language Center of National Education Department, 2008). While Suyanto (2009) defines character as a way of thinking and behaving that characteristic of each individual to live and work together, within family, society, nation, and country. A person who is said to have a character means he/she is a person who has personality, behavior, nature, or mental traits.

Character in a person is formed from the surrounding environment. These conditions then internalize into a characteristic, for example the family during childhood, and also innate (Koesoema, 2007). Lickona (1991) argues, the character refers to a series of cognitive, attitudes, motivation, behavior, and skills.

Treatment by repetitive mechanisms will form a certain behavioral habit (Slavin, 1994). Similarly, it needs various action to build behavior that can bring positive views, attitudes, and actions. Likewise, reading is an intellectual activity that can foster positive identity, views, attitudes, and actions (Guthrie, Schafer \& Hutchinson, 1991). Reading function itself can open up a wider horizon of knowledge, increase work productivity 
(Mikulecky, 1987). By reading, knowledge can be multiplied so that a human was not petty (Stanovich \& West, 1989).

Darmono (2007) states that reading is a tendency of the soul to encourage/motivate someone to do something about reading, a strong desire to conduct continuous reading activities (Deci \& Ryan, 2000; Guthrie et al., 2004a; Schiefele et al., 2012). Individual interests are usually made long-lasting and becoming long-lasting (Hidi, 2001). Reading aspect includes reading pleasure, awareness of reading benefit, frequency of reading, reading opportunities, and the number of reading books read. Reading like is not something that is born to someone but must be nurtured and maintained since he/she is still early, and it is a continuous process. We need to grow and develop reading behavior so that reading becomes a character.

Reading skill is a basic cultural value that individuals must have to overcome the challenges of times (Deci, Vallerand, Pelletier \& Ryan, 1991; Pintrich \& Schrauben, 1992). Dryden (1999) stated that SSR developed a systematic effort to familiarize the behavior of reading for students in America. Students show the phenomenon of declining in reading interest. This phenomenon has occurred also in various countries such as Singapore, Australia, Taiwan, and also in Indonesia. However, some countries have made serious efforts regarding the decrease of students' interest in reading activities. Some experts try to formulate ways for students to have a chance to get used to reading. The ways to get used to reading appear differently in some places but the spirit that carried is same. For instance, SSR types of programs are called "DEAR" (Drop Everything and Read), "squirt" (Silent, Quiet, Uninterrupted Individualized Reading Time), and "USSR" (Uninterrupted Sustained Silent Reading).Although there are variations in the format and implementation, the basic principles of time and ownership are the same.

In literatures there are terms that are different to call Reading Time program, such as Sustained Silent Reading Program (SSR), Free Voluntary Reading (FVR), Uninterrupted Sustained Silent Reading (USSR) and Positive Outcomes While Enjoying Reading (POWER) (Gardiner, 2005). In this activity, students are given freedom to choose their own books that they like and then they read the book for 15 to 20 minutes (Krashen, 2011). Sadoski (Yoon, 2002) also explains that in the implementation of the program, students are given freedom to choose the reading materials that they want. While the implementation of the program can also be done in the classroom, in the library or elsewhere in the school environment. Krashen and Cho (Pilgreen, 2000) describes the purpose of the program Reading Time. First, improve students' reading skill (Increase student reading proficiency). Reading Time Program is expected to make students have a high confidence that is a superior reader, according Kranshen and Cho a superior reader is a reader who are capable of having reading comprehension. Second, motivate students to read(Improve student motivation to read). Reading Time is an effort to increase students' interest in reading. By giving motivation to students to read, students are expected to read no longer as a saturating thing, but as a pleasure, for instance in this category is reading novels, newspapers, child encyclopedias, magazines, and comics. Third, as an effort to develop language (Facilitate overall language development). Reading Time Program in addition to increasing reading interest, as well as a means to develop language skills in students through both oral and written. 
A study conducted by Chua (2008), The Effects of the Sustained Silent Reading Program on Cultivating Students' Habits and Attitudes in Reading Books for Leisure produce two kinds of findings. First SSR program has a significant impact on the culture of students' reading habits. Second, SSR program affects the culture and the joy of reading of students.

In literatures, reading has been much studied the problem of reading behavior. The essence of reading behavior is a soul tendency to encourage someone to do something about reading (Sumadi, 1987). This reading behavior is indicated by a strong desire to perform reading activities. People who love reading will always fill the spare time by reading because they love the reading material. In contrast, the condition is different from people who have low reading behavior. Such people are usually reluctant to perform reading activities, the desire to read is very low. Reading is not interesting to them. People who like to read will often do reading activities. And, because they often read, it will be nurtured the reading habit. Reading, for them is a necessity. Such person would consider reading the morning paper, for example, as breakfast. By having a high reading habit, people will feel addicted to reading. Therefore, to develop reading behavior to the public, especially to students, with the $S S R$ approach requires a serious attention.

It is well known that reading behavior is one factor that significantly affects reading ability. People who love reading tend to have a good reading skill. A significant correlation between reading behavior and reading ability has been shown to be convincing in studies of reading. A close relationship between the two variables can be explained by the principles of learning to read, that is learning to read by reading (Smith, 1985; Gunning, 1991). This principle emphasizes that people learn to read is by doing the reading activity itself. The more often read the better the reading ability. Meanwhile, Supriyoko in his writing "Reading Interest and Quality of the Nation" in Kompas Tuesday, March 23, 2004, states: "Theoretically there is a positive relationship among reading interest with reading habit and reading ability. Low reading interest of society makes low reading habit, and this low reading habit makes low reading ability. That is what is happening to our society today".

Abdul Rahman Saleh in his writing "The Role of Information Technology in Enhancing Reading and Writing Like Society" states that a person's passion, like, or interest when it is correlated to reading, it can be measured through a process that begins with a person who has: (1) basic need for good information to read as well as to learn, (2) ability to respond and communicate the meaning in the reading materials (explicit, implied or whole comprehension), (3) establish the level of knowledge, and finally (4) positive attitude that reading is the part of life. Meanwhile, some literatures conclude that (1) children who read are usually able to write, talk, and understand ideas better than children who do not read, (2) children who read have wider insight, (3) children who read do not experience personality crisis on their academic ability, (4) children who read have opportunity and probability wider in understanding life, and (5) children who read are more creative and argumentative.

Some research results about reading show positive results (Lee, Y.O. Krashen and Gribbons, 1996; Constantino Lee, SY Constantino, Cho and Krashen, 1997; Lee SY, 2000). Krashen (in Pilgreen, 2001) suggests that free reading program in schools result in good reading 
comprehension. Anderson, 1996; Krashen, 1993; Nagy and Herman, 1987 (www.liberty.k12.mo.us/ms/LMC/SSR/SSR.ppt) states that SSR program greatly help to increase the mastery of new vocabulary. Likewise, Burley (Manning-Dowd, 1985) states he finds that SSR had a more positive effect on reading comprehension than three of practice methods. Holt (1988) finds that there were significant difference between Reviews those who received this program as part of the language arts block of instruction and Reviews those who used the basal reading series only. This statement indicates a significant difference with other methods of improving reading comprehension skill.

The basic theory of SSR is "The program is based on the belief that self-selection motivates students to read with interest, and the resulting extended period of practice improves Reviews their reading achievement (Karweit \& Slavin, 1981). Another important element of the SSR is modeling, based on the idea that effective learning results from following the example of another's model of behavior (Bandura, 1986). There are a number of principles in the implementation of the SSR, namely: (1) Students read whatever they like; (2) Short time-spans, 15 to 20 minutes; (3) Every day during school (Marshall, 2002). The objectives and benefits of SSR are (1) improving the proficiency of learners' reading comprehension, better confidence, and affecting their achievement; (2) improving students' reading motivation for being a reader of pleasure, developing the reading like.

There are 8 (eight) factors that influence the success of SSR implementation according to Pilgreen (2000), namely: (1) easiness in getting reading books, (2) interesting reading books, (3) conducive school climate, (4) condition which support students to read, (5) trained staffs, (6) unattended, (7) distribution of time for reading, and (8) follow-up. Some markers exist when SSR can run well in school, namely: (1) circulation of books in the library becomes swift, (2) students always ask for more books, (3) mutual borrowing among libraries, and (4) few books left in the library.

From the above description SSR has advantages and benefits to improve students' reading comprehension proficiency, better confidence, and effect to the performance and improve motivation to read because reading brings a sense of fun and develops reading like (Marshall; 2002). Researches about SSR approach are still rare in Indonesia so it is urgent to implement this approach.

SSR activities are carried out need an infrastructure readiness, namely: the number of books is adequate and the books are interesting, also adequate time to read in school. In establishing reading behavior, teachers play a greater role in establishing the behavior than parents. Because teachers have mastery and ability in the learning process so that the establishment of reading like behavior of SSR approach will be more effective and is expected to establish the students' character as the provision becoming the generation having wide insight, advanced and competitive characters.

Based on the above description, the research objectives are to: (a) describe the understanding of the school in the formation of reading behavior; (b) describe the quality and quantity of books owned primary school in Malang (c) describe the behavior of the model establishment likes to 
read the SSR approach; and (d) analyze the reading like behavior of elementary school students in Malang with SSR approach.

The practical purposes of this research were (1) to guide teachers in creating compulsive and fun conditions in reading for students of public elementary schools in Malang; (2) to create habits or traditions of reading together for a certain period of time at the same time, both students and teachers; And (3) teacher can understand the steps and strategies to understand the supporting tools in changing the reading environment.

\section{Research Methods}

This research used survey and experiment research design. The instrument used is questionnaire equipped with interviews and observation. The research experiment was done with treatment on students as follows.

\begin{tabular}{|c|c|c|c|}
\hline Subject & Pre Test & Duration of Treatment(SSR Approach) & Post Test \\
\hline Students & O1 & 1 months & $\mathbf{O 2}$ \\
\hline
\end{tabular}

Figure 1. Framework of Treatment in Read-Like Research

The population of this research was public elementary schools (SDN) in Malang city as many as 199 schools. The research used random sampling technique. The sampling steps were as the following steps: (1) SDNs in Malang City are grouped into 5 districts because Malang has 5 districts; (2) each SDN in one sub-district was arranged randomly; (3) 1 SDN in each sub-district was taken randomly, so that 5 SDNs were used as sample by using the 3rd grade students as many as 196 students. The data were collected using questionnaire, observation, and interview techniques. The data sources were students, teachers, principals, and library staffs.

These instruments which were used to collect the data related to (a) understanding of school parties on the establishment of reading like behavior with SSR; (B) data accuracy on the quality and quantity of reading books owned by the public elementary schools in Malang City; (c) model description in establishing the reading like behavior with SSR approach on the elementary school students in Malang City. The research instruments were: (a) questionnaires, to explore the data quality and quantity of the library books, the sources of data were the library staffs; (B) observation sheets, including data of the school identity and library condition, the sources of data were the principals and library staffs; (C) interview sheets, to record the data of the initial activity of establishment of reading like behavior of students, the sources of data are the principals and teacher of class III; (D) Pre-test and post-test sheets, to obtain the data about the students' responses in the reading activities to measure the behavior and character of reading like of students, the sources of data were the class III students; (E) student reading activity record book which contains the title and content of the books read, the number of books read which were filled out by the students; and (f)guideline of SSR management, the sources of data were the teachers. 
Based on the instrument types above the next step arranged the instrument contents, compiled the questions based on the contents made, examined the question items, and improved the instrument. Pre-test and post-test questionnaires were used to probe the reading like before and after treatment. Questionnaires were developed from the following indicators: (1) reading pleasure, (2) preferred reading book type, (3) origin of reading book, (4) reading place, (5) reading time and duration, (6) number of book read, and (7) awareness of the benefits of reading. They were spelled out in the descriptor by giving 22 items, each question has 3 alternative answers (a, b, c). Alternative answers are given scores: $a$ has score $1, b$ has score 2, and $c$ has score 3. The Grouping of reading like scores were formulated from pre-test and post-test: score of 22-36 is in low categories, 37-50 is in sufficient category, and 51-66 is in high category. Then it was done the validity and reliability test to the 22 item questions. Observations and interviews were set up in according to the type of data required.

In this research, quantitative analysis was used that is after data collection it was done the data review completely and accurately including: (a) categorizing and classifying data according to research problems, (b) data presentation and interpretation, and (c) data analysis according to research problems. Quantitative data analysis was used to describe the outcome achievement through descriptive study covering percentage and average. For quantitative analysis it was also used t-test by using SPSS version 19 for hypotheses test to the establishment of reading like behavior by $S S R$ approach, using $\alpha=0.05$. The research hypothesis was formulated on the basis of theoretical and empirical studies which suggest that SSR approach can improve the reading like behavior of students of SDNs in Malang City.

\section{Results and Discussion}

\subsection{Research Results}

The result of the school parties' understanding of the establishment of reading like behavior was that there was still no school party seeking the establishment of reading like behavior in a serious way. However, there were two sample schools providing special programs to read books in school at a certain time and it is only once a week. Teachers require students to bring free reading books or magazines from home to read in school. This step is quite positive although the frequency is still small. The results showed that treatment performed by repeated mechanisms will build a specific behavioral habit (Slavin, 1994). In addition, teachers also have not given opportunity to special time for students to read in the library, only two sample schools providing opportunities for students to read in the library at special hours every week. This method is a good step because in day-to-day students are too busy with the lessons to be followed, while the rest time is only 15 minutes based on observations during the study almost all students spend time off to play. This condition is still far from expectations, whereas Law no. 43 in 2007 about libraries wants a movement to develop reading like behavior. Likewise in realizing the reading like as one of the 18 characters (Kemendiknas, 2011). Therefore, to establish the reading like behavior schools should create conditions that can provide opportunities to read every day in school.

The establishment of reading like behavior certainly cannot be separated from the role of library in providing adequate reading books both in the quality and quantity and other library 
facilities. Three of five SDNs have their own library space while the two elementary schools are still combined with other activities. The appearance and condition of the room are not physically feasible for the ongoing reading activities comfortably. Only one elementary school has a library that is adequate although the area is limited. Thus, if two classes just go together in the library room, it is possible to make the condition becomes full and stuffy. Therefore, it needs to rotate in utilizing the library reading room. Another alternative is by borrowing books read in class/at home.

From five SDNs, two SDNs do not have librarians yet, while the other three schools have officers but they are not assigned specifically as librarians who only handle activities in the library but are caught up with other tasks.

The results of observations on books and interviews note that the library books owned by five SDNs are textbooks in majority compared to the non-reading books. The ratio of the number of students to the number of textbooks of all elementary schools is above $1: 6$, namely $1{ }^{\text {st }}$ SDN (1:6.3), $2^{\text {nd }}$ SDN (1:8.2), $3^{\text {rd }}$ SDN (1:7.5), $4{ }^{\text {th }}$ SDN (1:6.6), and $5^{\text {th }}$ SDN (1:6). When it was viewed from the number of existing lessons, it is quite adequate. The number of non-textbooks is sufficient for four elementary schools because they have ratio of the number of students to the number of textbooks which is above $1: 2$, namely $1^{\text {st }} \mathrm{SDN}(1: 4.2), 2^{\text {nd }} \mathrm{SDN}(1: 5,7), 3^{\text {rd }} \mathrm{SDN}$ (1:6.1), $4^{\text {th }}$ SDN (1:7.8), only one elementary school namely the $5^{\text {th }}$ SDN which has ratio of $1: 1.8$. The ratio of the number of students to non-reading textbooks is $1: 2$.

Based on the comparison of the number of non-textbook reading books with the number of students in general indicates that it is sufficient meaning that if all students borrow books then there is still an alternative choice of books.

In the term of book quality, book titles are not yet fully suitable for elementary school reading level. And from the novelty aspect of the books, most of them are old books, so students have a sense of boredom with the same books. There is an effort to add book collections from school operational grants (BOS), most of which are textbooks so they are not optimal. There are even schools having a number of books in the library with the condition of the book which is still very new, because the books have not been utilized by the students, although the book realization has been done long time ago, especially in elementary schools that do not have librarians. Such as the $1^{\text {st }} \mathrm{SDN}$, if the library condition is normal, the number of books compared to the number of students in each school is considered adequate. It is just because the limited human resource so that the library is not working properly.

Arranging books is also important to order neatly, beautifully, and easily to find. Unfortunately, the positioning of the book has not been well ordered because the books available are generally the school textbooks, whereas the free reading books have not been placed separately.

In the term of book lending circulation, because of the limited library staff in the SDN sample, the book lending service becomes obstructed and the book lending to take home is limited. While the opportunity for students to visit the library room is also limited because student visit can only be realized at the break time. The opportunity in break time is short, almost all students take the break opportunity to play freely. The $3^{\text {rd }} \mathrm{SDN}$ and $4^{\text {th }} \mathrm{SDN}$ in this 
research provide a solution for reading and lending services of books by giving opportunity to the existing classes to integrate the certain subjects with opportunity to enter the library room, but the book lending service is still minimal. It can be said that the circulation of book lending is low. Therefore, school managers should have more attention to the library. This is in line with the opinion of Kartono (Educational Newspaper, 2-7 July 2014) at least with the improvement of human resources, increasing the collection of books regularly, and making activities for children to be interested in library.

The establishment of reading like behavior with SSR approach has the following steps: (1) researchers provide a number of books, including (a) free reading books which have been through a selection according to the level of study, (b) control reading book, it is intended to control and manage the achievement of readings from each title of the book which students choose, (c) lending control book (held by teachers); (2) students in the class obtain: (a) opportunity to choose free reading books, (b) students are given 15 minutes to read, (c) reading control book; (3) after 15 minutes the teachers give students opportunity to summarize by using sentence according to the ability of students from the reading that they have read, the time to summarize is for 5 minutes; (4) after all activities done, students are required to collect the selected reading book and the reading control book, but if the selected textbook has not been fully read then the textbook is inserted into the control notebook to continue the next day; (5) The main task of teachers in the implementation of the SSR approach is to give instruction in accordance with the provisions, without giving any assessment; (6) all the activities are repeated every day.

The establishment of reading like behavior with SSR approach is something new, but during the research process, the understanding of school parties on the establishment of reading like behavior with SSR approach is good enough for the attention of the principals, teachers, and students are very high, so the application of the SSR approach can run smoothly without obstacles. The results of treatment for 1 (one) month, the respondents showed significant changes. As the result of pre-test and post-test, the initial percentage, there are $1.5 \%$ who chose the option of lazy reading, changed to $0 \%$ (zero) in the final test of treatment. Respondents who answered the option always wanted to read significantly improved. Initially only $73.5 \%$ to $88.8 \%$.

Any type of book, both textbooks and free reading books, is actually enjoyable for reading, because in pre-test $53.9 \%$ of respondents liked any kind of book then changed significantly to $69.6 \%$ on post-test results. In the meantime respondents prefer free reading books (fiction) and reading science books when compared to textbooks. Respondents stated, from the initial data of $49 \%$ to $82.1 \%$, that reading can be done anywhere. While the respondents stated that reading only done at school and at home as much as $51 \%$ decreased to $17.9 \%$.

For time to reading activities, they considered whenever can be used for reading activities. In the pre-treatment test of $66.1 \%$ they said they can do it indefinitely such as in the morning, noon, afternoon or evening. In the test after treatment it was obtained $72.2 \%$. There were significant changes. Reading only when they are directed, it had been reduced from $15.7 \%$ to $7.4 \%$ only. Such conditions, if the treatment is carried out in a longer time, it will allow the high 
increase significantly. The reading time increases. Initially respondents read maximum 1 hour per day which reached $48 \%$ changed to $28.6 \%$, between 1 to 2 hours the initial activity which was $34.8 \%$ reached to be $44.4 \%$. And, more than 2 hours, the initial activity which was only $17.2 \%$ increased to $27 \%$.

When it is asked about the preference for reading textbooks before and after treatment is the same as much as $81.1 \%$ meaning that they like reading textbooks. And, $18.9 \%$ are choosing less like reading and do not like reading textbooks. How the role of teacher is to make the respondents like reading textbook, the initial data was $69.6 \%$ of respondents feel that the teacher asked to read the textbook but after treatment with SSR approach it reduces as much as $60.9 \%$ meaning that there is a growth in the respondents to initiate reading.

Peers play a big role in growing reading like behavior. Initially, teachers have a big role but then it is changed. Peers from the initial activity which was only $1.9 \%$ changed to $48 \%$ at the end of the treatment. Similarly, the initiative to read which was only from $33.4 \%$ changed to $51 \%$. While at home, the activity of reading textbooks is more on the basis of self-desire, before treatment it was $34.7 \%$ and after treatment it was $51.1 \%$. The rest is based on the encouraged by parents, brothers or sisters, and friends. Respondents who love reading free reading books very much reached $81.4 \%$ before treatment and became $87.3 \%$ after treatment. The rest was less like. While at home reading free reading books, before treatment respondents were $38.2 \%$ bytheir serves interest and $55.9 \%$ by the encouragement of parents. However, after the treatment, respondents who answered by their serves interest reached $68.9 \%$ and parents' encouragement became $29.1 \%$. The rest was by the encouragement of friends.

Within a month the number of books read, before treatment, respondents who answered less than 10 books reached $49 \%$ and more than 30 new books reached $22.5 \%$. But after the treatment, the respondents who had read less than 10 books were only $9 \%$ and had read 11 to 30 books were $50 \%$, while more than 30 books were $41 \%$. Whereas, the story books read in a week before treatment with 1 book was $19,1 \%$, after treatment it was only $6,1 \%$. Reading 2 to 3 stories reached $3.6 \%$ and after treatment it changed to $40.8 \%$. While the respondents who were able to read more than 3 stories amounted to $37.3 \%$ changed to $53.1 \%$. Thus there is an increase in the acceleration of reading ability of the respondents.

The respondents' responses to science reading books as follows, before the treatment, the respondents who did not like as much as $7.8 \%$ decreased to $6.1 \%$ after treatment. While the respondents who liked as much as $19.2 \%$ changed to $18.9 \%$. The Preference is high for respondents who love reading science books very much before treatment was $73 \%$ and after treatment was $75 \%$ of respondents. The Respondents' response to their reading like of science books based on motivation affecting them at home, it turns out, before treatment the influence of friend was $9.8 \%$ and after treatment it decreased by $3.6 \%$. Parents, from $58.8 \%$ decreased to $45.4 \%$. Precisely the sharp rise is on the basis of their own desire to read science books which was from only $31.4 \%$ to $51 \%$ of respondents. The response of respondents who read the science book only 1 book in a week, in the initial activity was $19.2 \%$ changed to $14.8 \%$. Read 2 to 3 books, initially was $40.6 \%$ changed to $33.2 \%$. While more than 3 books in a week, initially was $40.2 \%$ after treatment it changed to $52 \%$. 
When it was asked whether there is a special time to read the textbook, respondents answered that there was no special time was $12.3 \%$ it changed to $0 \%$ after treatment, sometimes there was special time was $18.6 \%$ after treatment it decreased to $3 \%$. There was a special time was $69.1 \%$ after the treatment it increased to $97 \%$. The activity of reading book once a week at the respondent's school was answered once (1) by $16.3 \%$ after the treatment it decreased to $0 \%$. Read 2 to 3 times as much as $31.5 \%$ after treatment it decreased dramatically to $2 \%$. Every day respondents answered as much as $51.9 \%$ and after treatment it increased significantly to $96 \%$.

For reading book at school, respondents who answered was done in the classroom was $15.7 \%$ after the treatment it increased to $53 \%$, in the library room as much as $36.8 \%$ after the treatment it decreased to $10 \%$, and respondents as much as $47.5 \%$ answered implemented wherever after treatment decreased to $35 \%$. Respondents, when given a special time to read a free reading book, initially as much as $72.1 \%$ of respondents who answered very happy, but after treatment, $93.1 \%$ of respondents answered very happy. The time used to read free reading books, $53.9 \%$ of respondents answered before the break time, after the lesson ended before returning home was $21.6 \%$, and respondents who answered before the lesson started was $24.5 \%$.

Based on the results of the validity and reliability test results from the questionnaire for pre-test and post-test it was obtained all items have a significant level of validity and reliability because the level of significance is smaller than $\alpha=0.05$. Furthermore, the score of the questionnaire results before treatment and after treatment to the 5 SDNs with the number of samples of 196 students were analyzed by t-test to compare whether there was a significant difference or increase.

The result of data analysis of all samples through t-test with paired sample test obtained that $t$ value was equal to 14.713 with $\mathrm{df}=195$ and significance 0.000 was smaller than $\alpha=0,05$ meaning there is a significant difference to readers' reading like before and after application of SSR approach. The difference is indicated by the mean value after the treatment is higher than before the treatment where after treatment the Mean value (My) is54.934 (classified as high reading like) and before the treatment it has Mean (Mx) of 49.199 (classified as quite reading like). The improvement of students' reading like is because of the results of treatment for 1 month. During 1 month students have been accustomed to reading. This habit will continuously build the character. Lickona (1991) states that a person's character will be built through a long process through habit.

The data analysis results of the first SDN was obtained t-value was 9.593 with $\mathrm{df}=40$ and significance 0.000 was smaller than $\alpha=0.05$. This means that there is a significant difference to the students' reading like before and after SSR application. The difference is indicated by the mean value after the treatment is higher than before the treatment. The Mean after treatment is equal to 55.341 (categorized as high reading like) and Mean before treatment is equal to 48.951 (categorized as quite reading like). This shows that the first SDN has Mean after treatment is above average of all SDN samples as much as My=54.934.

The result of data analysis of the second SDN was obtained t-value was equal to 6.126 with $\mathrm{df}=39$ and significance 0.000 was less than $\alpha=0,05$. This result means that there is a significant difference to the students' reading like behavior with SSR implementation. The difference is 
indicated by the mean value after treatment $=54.20$ (categorized as high reading like) is higher than the Mean before the treatment as much as 49,222 (categorized as quite reading like).

The data analysis results of the third SDN was obtained t-value was 5.296 with $\mathrm{df}=40$ and significance 0.000 was smaller than $\alpha=0.05$. This result means that there is a significant difference to students' reading like behavior before and after the SSR approach. The Mean value after treatment equal to 53,766 (categorized as high reading like) is higher than Mean before treatment equal to 49,610 (categorized as quite reading like). Although the third SDN has Mean after the treatment below the average of all SDN samples that is My=54.934, but there is an increase of average value after treatment than before treatment with SSR approach.

The data analysis result of the fourth SDN was obtained t-value was 5.296 with $\mathrm{df}=40$ and significance 0.000 was smaller than $\alpha=0.05$. This result means that there is a significant difference to students' reading like before and after SSR approach. The difference is indicated by the mean value after the treatment which is higher than before the treatment. After the treatment of Mean value as much as 53.103 (categorized as high reading like) and before the treatment of Mean value as much as 47.744 (categorized as quite reading like). This shows that the fourth SDN has Mean below the mean of all SDN samples that is equal to My=54.934 and $\mathrm{Mx}=48.199$. However, an increase in mean value after treatment compared to before treatment with SSR approach is significant.

The data analysis result of the Fifth SDN was obtained t-value was 8.336 with $\mathrm{df}=34$ and significance 0.000 was smaller than $\alpha=0.05$. These results indicate that there is a significant difference to students' reading like behavior before and after the adoption of SSR approach. The difference is indicated by the mean value after the treatment is higher than before the treatment. After treatment it has Mean as much as 58.714 (categorized as high reading like) and before the treatment has Mean as much as 50.00 (categorized as quite reading like). This shows that the fifth SDN has Mean above the mean of all SDN samples namely My=54, 934 and $\mathrm{Mx}=48.199$.

\subsection{Discussion of the Research Results}

Based on the result of t-test above it shows that with SSR approach students' reading like behavior after treatment for 1 month becomes increase which is indicated by increasing of mean value from data analysis results. This is also supported by the responses of respondents to questionnaires showing that respondents like reading very much with increasing percentage, especially for questionnaires who say very happy to read after the SSR treatment and no more students are lazy to read. These results are supported by Burley (Manning-Dowd, 1985), Nagy and Herman (1987), Holt (1988), Krashen (1993), Anderson (1996), Krashen (Pilgreen, 2001), Marshal (2002) Chua (2008).

Burley (Manning-Dowd, 1985) states that SSR has a more positive effect on reading comprehension than the other three practice methods. Meanwhile, Holt (1988) states there is a significant difference between those who receive the SSR program as part of the art block of introduction language and those who only use it as a series of reading. 
On the other hand, Nagy and Herman (1987), Krashen (1993) and Anderson (1996) state that SSR programs are helpful in improving new vocabulary mastery. Dryden (1999) states that SSR is a systematic effort developed to familiarize reading behavior. While Marshal (2002) states that SSR improves students' reading motivation because reading brings pleasure, develops reading love. Chua (2008) states that the SSR program has a significant impact on the culture of reading habits of students, and affects the culture of pleasure and enjoyment of reading students. This is paralleled by Deci, Vallerand, Pelletier \& Ryan, 1991 and Pintrich \& Schrauben, 1992.

Similarly Melisa Kakaina (without years) and Ira Uffa Dwi Ratih Fijayanti (no year). Kakaina found that most students feel the benefits of adding new knowledge, so they are motivated to read more. Like Mikulecky, 1987, Fijayanti finds that the SSR program is an effective program for improving the reading and writing skills seen from the students' pleasure when following the programs and work that students have produced, SSR programs also motivate students to read.

Based on the results of research and supporting theories it can be said that the results of this study is to reinforce both the results of previous research and supporting theories. It is said that because the results of previous research concluded that the implementation of the SSR program can improve students' reading like behavior. While the results of this research also show that the implementation of SSR program can improve students' reading like behavior because the student's average score increases. Similarly, students' responses to reading questionnaires indicate an increasing percentage, especially for questionnaires who say they are happy to read after the SSR program. No more students are lazy to read.

\section{Conclusions and Suggestions}

The understanding of the school parties against the establishment of reading behavior before the treatment was still bad, it was proved that there is no school party seeking the formation of reading behavior in a serious way. However, after the treatment of SSR approach the schools' understanding of the establishment of reading like behavior is good.

The role of library in supporting the establishment of reading like behavior has not been as expected, especially in the quality of textbooks, although the number of available books is quite rational but the many books available are old and under-titled. In addition, the librarian staffs have other duties or jobs and have not had adequate capability. The SSR approach model gives students the ease to get their preferred books and reading opportunities on a regular basis.

The adoption of SSR approach has significantly improved on reading like behavior. Students feel happy to read, for a month they already have a habit of reading that makes the basis of the character building. Therefore, the implementation of SSR approach model needs to be sustainable.

The principal in the use of BOS funds for the procurement of books should be new books that are favored by students but have quality namely books that have a content of education values. Therefore, it is necessary to form a selection team of reading books in schools, especially books available in the library. 
For the sustainability of reading habits that have been built during the implementation of SSR model, in order to establish a sustainable reading like behavior, principals and teachers should create conditions that are enable for students to read continuously every day at school. Likewise, Education Office (Diknas) should create a new policy on librarian procurement for schools so that the library can be well managed.

\section{Acknowledgement}

The research is financed by the General Directorate of Strengthening Research and Development, Ministry of Research, Technology, and Higher Education

\section{References}

Bandura, A. (1986). Social foundations of thought and action: A social-cognitive theory. EnglewoodCliffs, NJ: Prentice Hall.

Constantino, R., Lee, S.Y., Cho, K.S., and Krashen, S. (1997). Free voluntary reading as a predictor of TOEFL scores.Applied Language Learning, 8, 111- 118.

Darmono. (2007). Perpustakaan Sekolah Pendekatan Aspek,Manajemnen dan Tata Kerja, Jakarta: Gramedia Nidiasarana Indonesia.

Dryden, Gordon, Vos, Jeannette. (1999). The Learning Revolution, To Change The Way The world Learns, The Learning Web, Torrance, CA., USA.\& Auckland, New Zeland.

Emzir. (2011). Metodologi Penelitian Pendidikan, Kuantitatif dan Kualitatif. Jakarta: Rajawali Press. Cet. ke 5.

Guthrie, J.T., Bennet, L., \& McGough, Karen. (2009). Concept Oriented Reading Instruction (CORI): An Integrated Curriculum to Develop Motivation and Strategies for Reading, Diambil tg1 9 Oktober 2012 dari http://www.curry .virginia. edu/go/clie/ nrrc /cori_r10 html.

Hidi, S. (2001). Interest, Reading, and Learning: Theoritical \& Practical Consideration. Educational Psychology Review, 13(3). https://doi.org/10.1023/A:1016667621114

Holt. (1988). The Effect of Sustained Silent Reading and Writing on Achivement and Attitudes of Seventh and eight grade Student Reading Two Years Below Grade Level (micrform)http://www.eric.ed.gov/ contentdelivery/servlet/ERICServlet? accno . (2006). Biro Pusat Statistik, http://www.bps.go.id. Diakses 13 maret 2013).

\footnotetext{
gital_Docs/homepage_folders/ activities/highlight/ruu_perpustakaan/pdf/UU_43_2007_PERPUSTAKAAN.pdf . (2008). Kamus Bahasa Indonesia, Jakarta: Pusat Bahasa Depdiknas. . Sustained Silent Reading, Liberty Public School, www.liberty. k12.mo.us/ ms/LMC/ SSR/SSR.ppt
} 
Kamah, Idris, et.al.(2002). Pedoman Pembinaan Minat Baca, Jakarta: Perpustakaan Nasional RI.

Kartika, E. (2004). Memacu Minat Membaca, Jurnal Pendidikan Penabur - No.03. Th.III / Desember 2004.

Karyono, Koran Pendidikan, Edisi 520/1/2-7 Juli. (2014). Perpustakaan Pacu Minat Baca, hlm. 8 .

Karweit, N., \& Slavin, R. (1981). Measurement and modeling choices in studies of time and learning. American Educational Research Journal, 18, 157-171. https://doi.org/10.3102/00028312018002157

Kementerian Pendidikan Nasional. (2011). Panduan Pelaksanaan Pendidikan Karakter. Jakarta: Badan Penelitian dan pengembangan Pusat Kurikulum dan Perbukuan.

Koesoema, Doni A. (2007). Pendidikan Karakter: Strategi Mendidik Anak di Zaman Global. Jakarta: Grasindo. Cet. I

Lee, Y.O., Krashen, S., and Gribbons, B. (1996). The effect of reading on the acquisition of English relative clauses. ITL: Review of Applied Linguistics 113- 114: 263-273.

Lee, S.Y. (2000). What Makes It So Difficult to Write. Taipei: CranePublishing Company.

Lickona, Thomas. (1991). Educating for Character: How Our School Can Teach Respect and Responsibility. New York, Toronto, London, Sydney, Aucland: Bantam books.

Manning_Dowd, Alice. (1985). The Efectiveness of SSR: Review of Research (ED276970). http://eric.

ed.gov/ERICWebPortal/search/detailmini.jsp?_fpb=true\&_\&ERICExtSearch_SearchValue_0 $=$ ED418379\&ERICExtSearch_SearchType_0=no\&ac.

Marshall, Jodi Crum. (2002). Are They Really Reading? Expanding SSR in the Middle Grades. Portland, Maine: Stenhouse Publishers.

Pilgreen, Janice L. (2000). How to Organize and Manage a Sustained Silent Reading Program. The SSR Handbook:Portsmouth, NH:Heine- mann Boynton/CookPublisher

Santoso, S., 2011, Mastering SPSS Versi 19, Jakarta: PT Elex Media Komputino.

Slavin, R. E. (1994). Educational Psychology, Theory \& Practice, Boston, London, Toronto, Sydney, Tokyo, Singapore: Allyan \& Bacon.

Stephen,Jessica. (2010). World education rankings: which country does best at reading, maths andscience? The Guardian,http://www. guardian.co.uk/ news/data blog/2010 /dec/ 07/world-education-rankings-maths-science-reading\#data.

Suyanto. (2009). Pendidikan Karakter. Diunduh tgl 28 Maret 2013 .http://www.mandik-dasmen. Depdiknas. go.id/ 